\title{
ELECTROLYSIS OF MOLTEN NITRATES ON GRAPHITE ELECTRODES: KINETICS OF THE ANODIC REACTION*
}

\author{
A. J. Arvía and W. E. Triaca \\ Instituto Superior de Investigioneacs, Facultad de Química y Farmacia, Universidad \\ Nacional de La Plata, La Plata, Argentina
}

Abstract--The anodic reaction occurring during the electrolysis of molten nitrates on graphite electrodes at temperatures from 230 to $320^{\circ} \mathrm{C}$ has been studied. The overall reaction is

$$
2 \mathrm{NO}_{3}-+\mathrm{C}=\mathrm{CO}_{2}+2 \mathrm{NO}_{2}+2 \mathrm{e} \text {. }
$$

Current/voltage curves in the range $0.5-200 \mathrm{~mA} / \mathrm{cm}^{2}$ fit a Tafel line with a slope $2 R T / F$. The decay of anodic overvoltage is logarithmic with time in a region beyond $10 \mathrm{~ms}$, depending on the current density. The decay process indicates a high pseudo-capacitance, which decreases as the anodic overvoltage increases.

Results obtained from steady current/voltage curves, decay and build-up of the anodic overvoltage, and the temperature effect can be explained with the aid of known results on the kinetics of thermal oxidation of graphite and on the anodic reaction taking place on platinum electrodes. At high overvoltage a high degree of oxidation caused by the $\mathrm{NO}_{3}$ intermediate is achieved, and the rate-determining step of the anodic reaction is then

$$
\mathrm{C}(\mathrm{O})+\mathrm{NO}_{3}^{-} \rightarrow \mathrm{NO}_{2}+\mathrm{CO}_{2}+\mathrm{e} \text {. }
$$

A stable residual cell formed after the interruption of electrolysis is discussed in terms of the reactions in the proposed reaction path.

Résumé--Etude de la réaction anodique dans l'électrolyse sur électrode de graphite des nitrates fondus, entre 230 et $320^{\circ} \mathrm{C}$. La réaction globale est

$$
2 \mathrm{NO}_{3}^{-}+\mathrm{C} \rightarrow \mathrm{CO}_{2}+2 \mathrm{NO}_{2}+2 \mathrm{e} \text {. }
$$

Les courbes courant/tension satisfont à une droite de Tafel de pente $2 R T / F$ entre 0,5 et $200 \mathrm{~mA} / \mathrm{cm}^{2}$. La décroissance de la surtension anodique est logarithmique en fonction du temps dans une région autour de $10 \mathrm{~ms}$, selon la densité de courant. Le processus dénote une pseudo-capacitance élevée, qui décroít quand la surtension anodique augmentc.

Des résultats connus, sur l'oxydation thermique du graphite et sur la réaction anodique aux électrodes de platine, expliquent assez bien les particularités des courbes stationnaires courant/tension. A de fortes surtensions, un degré d'oxydation notable est du à l'intermédiaire $\mathrm{NO}_{3}$ et l'étape régulatrice de la réaction anodique devient

$$
\mathrm{C}(\mathrm{O})+\mathrm{NO}_{3}{ }^{-} \rightarrow \mathrm{NO}_{2}+\mathrm{CO}_{2}+\text { e. } .
$$

On discute, sur la base des réactions présumées du mécanisme, la nature de la cellule stable obtenue après interruption de l'électrolyse.

Zusammenfassung-Man untersuchte die anodischen Reaktionen, welche sich während der Elektrolyse von Nitratschmelzen an Graphitelektroden bei Temperaturen zwischen 230 und $320^{\circ} \mathrm{C}$ abspielen. Die Bruttoreaktion ist:

$$
2 \mathrm{NO}_{3}-+\mathrm{C}=\mathrm{CO}_{2}+2 \mathrm{NO}_{2}+2 \mathrm{e} \text {. }
$$

Stromspannungskurven im Bereich von $0,5-200 \mathrm{~mA} / \mathrm{cm}^{2}$ ergeben Tafel-Geraden mit der Steigung $2 R T / F$. Der Abbau der anodischen Uberspannung ist ab $10 \mathrm{~ms}$ nach Stromabschalten eine logarithmische Funktion der Zeit und hängt von der Stromdichte ab. Die Abfallkurven deuten auf eine hohe Pseudokapazität hin, welche mit steigender anodischer Überspannung abnimmt.

Die aus stationären Strom/Spannungskurven, Abschalt- und Einschaltkurven und dem Temperatureinfluss erhaltenen Resultate können mit Hilfe von bekannten Ergebnissen der Kinetik der thermischen Oxydation von Graphit und der an Platinelektroden sich abspielenden anodischen

* Manuscript received 7 July 1965. 
Reaktionen erklärt werden. Bei grossen Überspannungen wird ein hoher Oxydationsgrad der Elektroden erreicht, welcher durch das $\mathrm{NO}_{3}-$ Zwischenprodukt erzeugt wird; der geschwindigkeitsbestimmende Schritt in der Anodenreaktion ist dann

$$
\mathrm{C}(\mathrm{O})+\mathrm{NO}_{3}^{-} \rightarrow \mathrm{NO}_{2}+\mathrm{CO}_{2}+\mathrm{e} .
$$

Eine stabile Restspannungszelle, welche sich nach Abschalten des Elektrolysestroms ausbildet, wird mittels der im vorgeschlagenen Reaktionsweg sich abspielenden Reaktionen erklärt.

\section{INTRODUCTION}

IN PRLVIous publications ${ }^{1-3}$ a detailed thermodynamic and kinetic analysis of the anodic reactions taking place on platinum electrodes during the electrolysis of molten nitrates at temperatures from 220 to $470^{\circ} \mathrm{C}$ was made. Results obtained in the lower temperature region were satisfactorily explained from the thermodynamic point of view, on the basis of the existence of a reversible nitrate electrode. From the kinetic point of view a mechanism was proposed to give a coherent interpretation of the experiments, which involved two kinetically significant steps, namely; the initial discharge of nitrate ion, yielding $\mathrm{NO}_{3}$ as intermediate on a particular site of the electrode surface, and the subsequent decomposition of the $\mathrm{NO}_{3}$ yielding nitrogen dioxide and an oxygen atom probably retained on the electrode surface. As the reactions are differently dependent on the electrode potential, the former appears as the rate-determining step at high overvoltage while the latter controls at low overvoltage.

To throw further light on part of the reactions entering the discharge of nitrate ions it was considered of interest to study the reaction occurring on graphite electrodes of the highest purity. The nature of the postulated intermediate in the initial discharge of nitrate ions gives the possibility following reactions that are different on graphite and on platinum.

It was also interesting to establish if, when graphite electrodes are used, the reaction path is modified within the temperature range from 220 to $470^{\circ} \mathrm{C}$. This is certainly the case: the electrochemical reactions are different in the lower and the higher temperature regions as recently reported. 4 This paper deals with the results obtained in the range of $230-320^{\circ} \mathrm{C}$ where the electrochemical reaction can be reasonably interpreted with a relatively simple reaction scheme.

\section{EXPERIMENTAL TECHNIQUE}

The electrolysis cell was essentially that described previously, ${ }^{3}$ but the anode was a spectroscopically pure graphite rod from "National", dia $3 \mathrm{~mm}$ and with an apparent surface which varied from 2.0 to $6.0 \mathrm{~cm}^{2}$. A platinum wire mechanically attached to the upper end of the rod held the electrode in position and provided a good electrical contact. The upper end of the anode was adjusted to the end of a Pyrex tube. New anodes were used in each series of experiments.

When pure silver nitrate, and silver nitrate dissolved in a $1: 1$ sodium-nitratepotassium-nitrate eutectic $(0.5-2.0 \mathrm{M})$, were employed as electrolyte, a silver cathode was used, but when the eutectic alone was electrolysed, a stainless steel cathode placed in a cathode compartment was employed. A silver/silver-ion or a nitrate electrode were indifferently used as reference electrodes.

The preparation of the electrodes, the purification of the electrolytes and the measuring devices have been described elsewhere. ${ }^{3}$ The gaseous products yielded by the anodic reaction were identified by ir-spectrometry. 


\section{Intensity/voltage curves}

\section{RESULTS}

Figures 1 and 2 show intensity/voltage curves plotted according to a Tafel equation

$$
\eta=a+b \log i
$$

where $a$ and $b$ are the well known Tafel constants. The overvoltage $\eta$, was corrected for ohmic overpotential. The ohmic drop was measured independently as described earlier. The overvoltage was referred to the stable open-circuit potential observed after the interruption of the electrolysis.

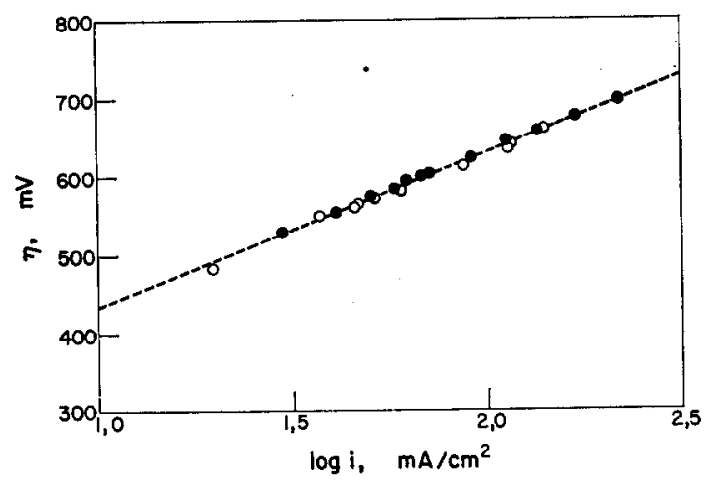

FIG. 1. Tafel plot. $221^{\circ} \mathrm{C}$; electrolyte: $\mathrm{AgNO}_{3}$; apparent anode area: $2.14 \mathrm{~cm}^{2}$. e, increasing potential; $O$, decreasing potential. The slope of the dotted line is $2 \cdot 3(2 R T \mid F)$.

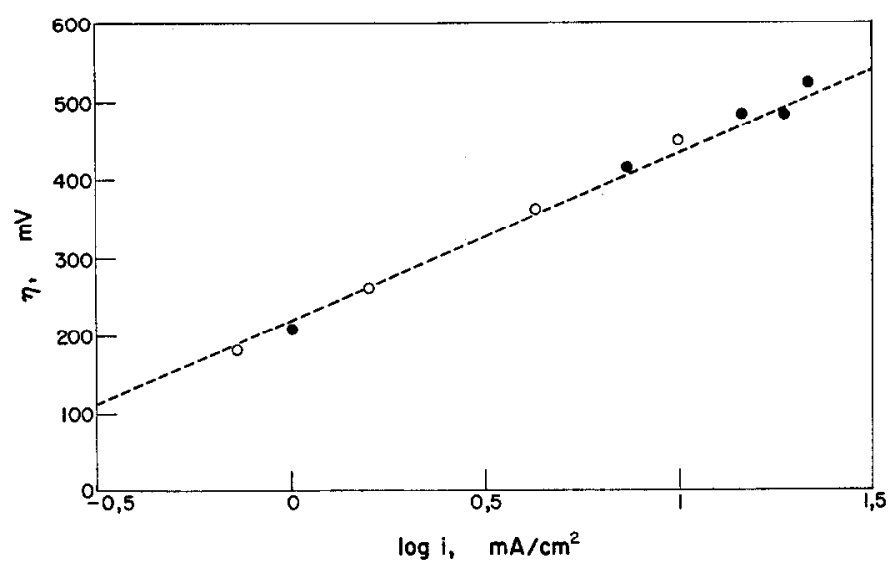

FIG. 2. Tafel plot. $266^{\circ} \mathrm{C}$; electrolyte: $\mathrm{NaNO}_{3}-\mathrm{KNO}_{3}(1: 1)$; apparent anode area: $6.95 \mathrm{~cm}^{2}$.

$\bullet$, increasing potential; $O$, decreasing potential. The slope of the dotted line is $2 \cdot 3(2 R T / F)$.

Experimental data obtained by raising and lowering the voltage lie satisfactorily well on a straight line with a slope of $2 \cdot 3(2 R T / F)$. By extrapolating the straight line at $\eta=0$, values of the corresponding current density, $i_{\eta=0}$, which are assembled in Table 1 for experiments done under different conditions, were calculated. Data indicate that $i_{\eta=0}$ increases with temperature. From a $\log i_{\eta=0} v s 1 / T$ plot, the 
experimental activation energy, $E_{\mathrm{a}}$, is $6.5 \pm 1.0 \mathrm{Kcal} / \mathrm{mol}$. Current densities are referred to the apparent area of the working electrode.

TABLE 1

\begin{tabular}{cccc}
\hline $\begin{array}{c}\mathrm{T} \\
{ }^{\circ} \mathrm{C}\end{array}$ & Electrolyte & \multicolumn{1}{c}{$\begin{array}{c}b \\
\mathrm{~V}\end{array}$} & $\begin{array}{c}i_{\eta=0} \times 10^{4} \\
\mathrm{~A} / \mathrm{cm}^{\mathbf{2}}\end{array}$ \\
\hline 221 & $\mathrm{AgNO}_{3}$ & $\mathbf{0} 196 \pm 0.010$ & $0.65 \pm 0.15$ \\
238 & $\mathrm{KNO}_{2}-\mathrm{NaNO}_{3}(1: 1)$ & $\mathbf{0 . 2 0 3}$ & 0.92 \\
266 & $\mathrm{KNO}_{3}-\mathrm{NaNO}_{3}(1: 1)$ & $\mathbf{0 . 2 1 4}$ & 0.99 \\
269 & $\mathrm{KNO}_{3}-\mathrm{NaNO}_{3}(1: 1)$ & 0.215 & 1.25 \\
\hline
\end{tabular}

\section{Overvoltage decay}

Typical decay curves are shown in Figs. 3, 4 and 5, where the overvoltage is plotted against $\log$ (time). The dotted straight lines in the figures correspond to a slope $-2 \cdot 3(2 R T / F)$. The data indicate that the straight line portion is reached the sooner, the higher the current density of the previous electrolysis. Once the straight line portion is reached, the points fall on the same line, independently of the current density used. The time dependence of the overvoltage at current interruption is withheld if oxygen is bubbled through the electrolyte in the anodic section of the cell, but a longer time is then required for the overvoltage to reach the straight line portion of the $\eta / \log$ (time) plot.

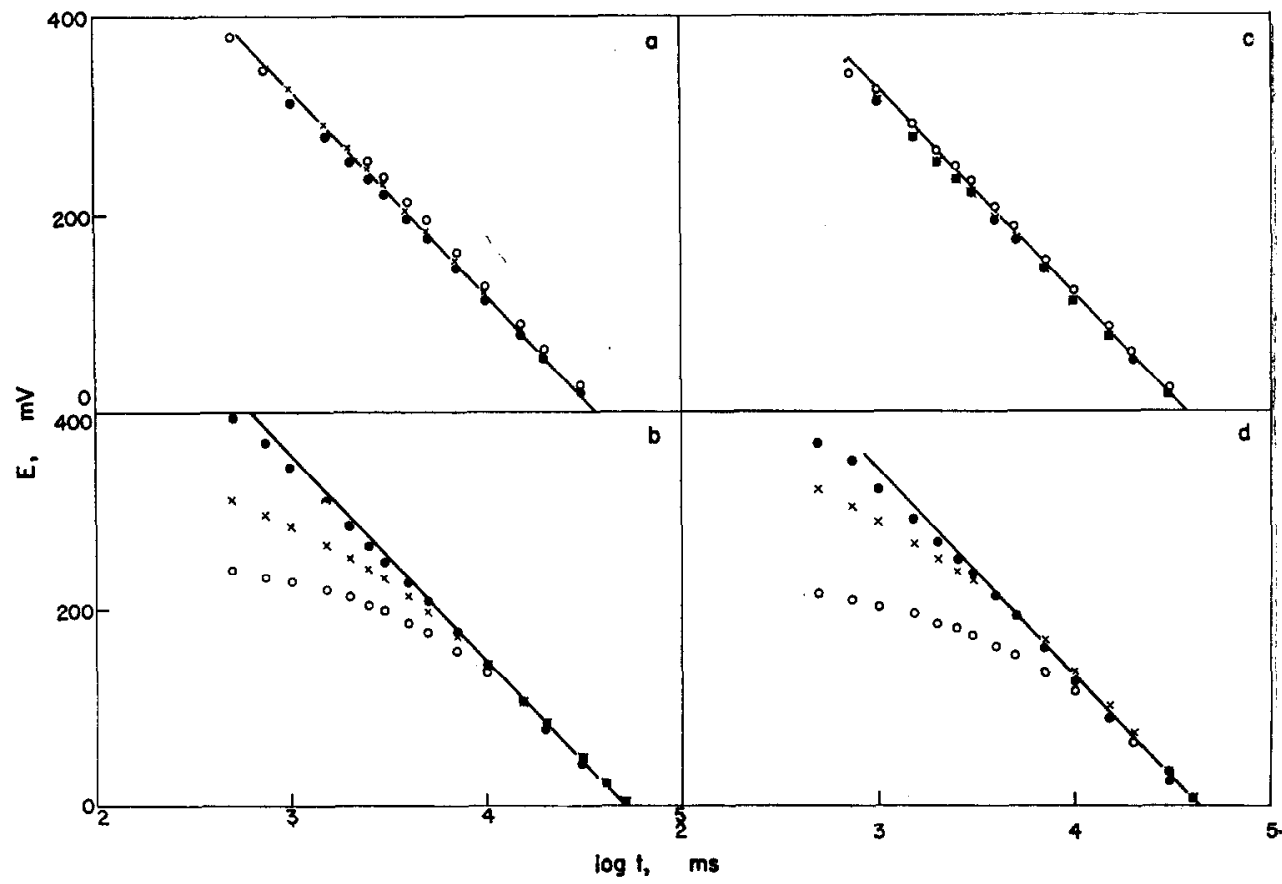

FIG. 3. Decay of anodic overvoltage. Potential $/ \log$ (time) plot. $258^{\circ} \mathrm{C}$; electrolyte:

$\mathrm{NaNO}_{8}-\mathrm{KNO}_{3}-\mathrm{AgNO}_{8}$ and oxygen bubbling; apparent electrode area: $1.77 \mathrm{~cm}^{2}$.

(a) $\bullet(117 \mathrm{~mA}), \times(83.5 \mathrm{~mA}), \bigcirc(50.0 \mathrm{~mA})$-anode $v s$ large surface silver cathode.

(b) $(27.5 \mathrm{~mA}), \times(16.5 \mathrm{~mA}), \bigcirc(7.5 \mathrm{~mA}$-anode vs large surface silver cathode.

(c) $(122 \mathrm{~mA}), \times(99.0 \mathrm{~mA}), \mathrm{O}(60.0 \mathrm{~mA})$-anode $v s$ reference electrode.

(d) $(46.0 \mathrm{~mA}), \times(15.0 \mathrm{~mA}), \bigcirc(6.2 \mathrm{~mA})$-anode $v s$ reference electrode.

Straight lines have slope $2 \cdot 3(2 R T / F)$. 


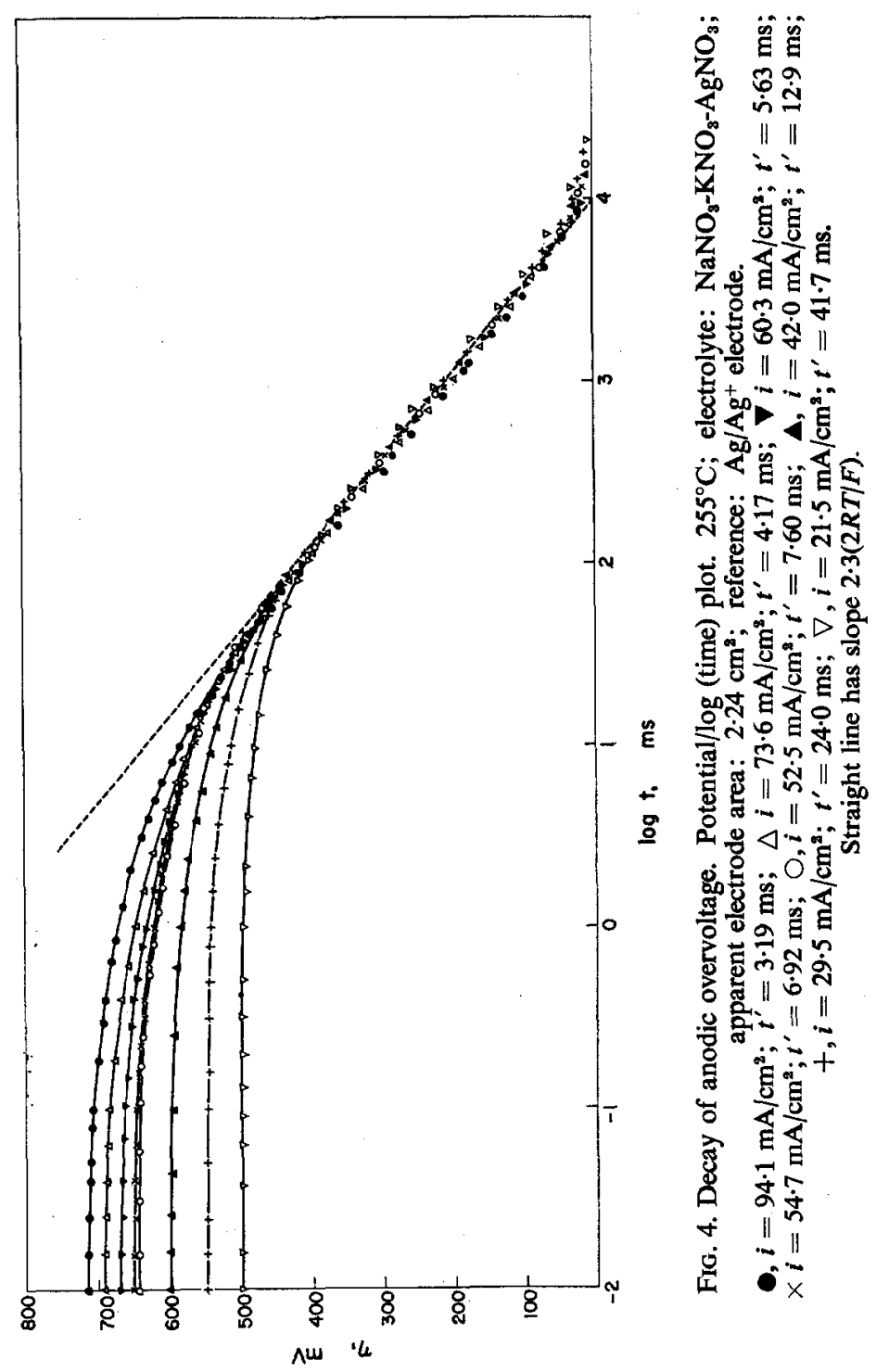




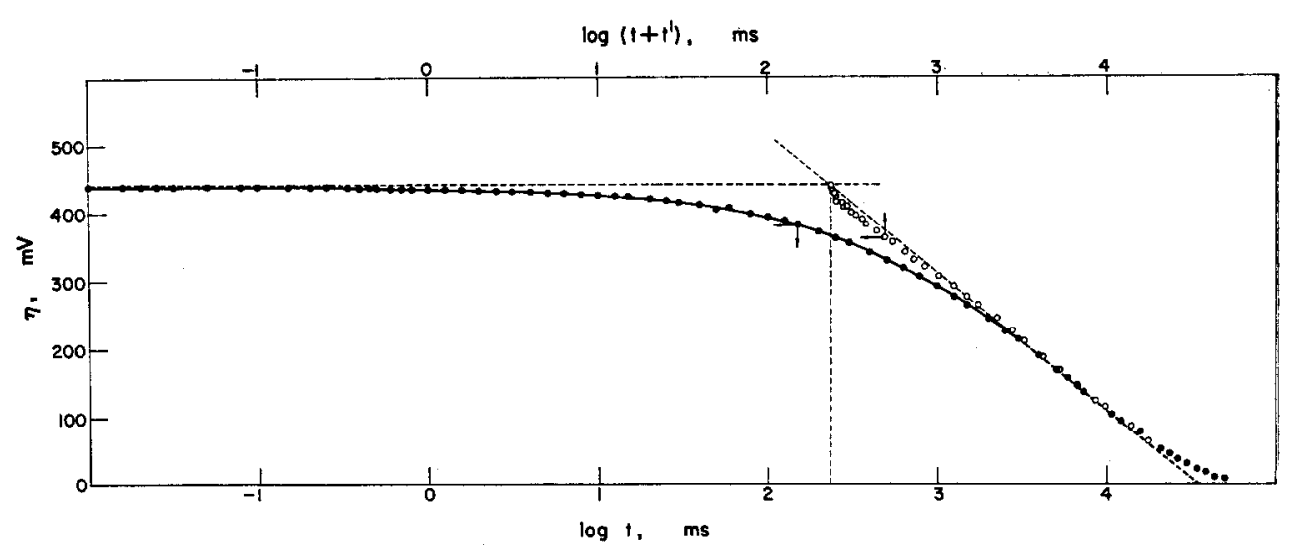

Fig. 5. Decay of anodic overvoltage. Potential $/ \log ($ time $)$ and potential $/ \log \left(t+t^{\prime}\right)$ plots. $238^{\circ} \mathrm{C}$; electrolyte: $\mathrm{NaNO}_{3}-\mathrm{KNO}_{3}$; apparent electrode area: $6.85 \mathrm{~cm}^{2}$; reference: $\mathrm{Pt}, \mathrm{NO}_{2}(\mathrm{~g}), \mathrm{O}_{2}(\mathrm{~g}) / \mathrm{NO}_{3}{ }^{-}$electrode. $i=8.8 \mathrm{~mA} / \mathrm{cm}^{2} . t^{\prime}=234 \mathrm{~ms}$.

The intersection of the straight line with the asymptotic line drawn parallel to the $\log$ (time) axis at the initial potential yields the value of $t^{\prime}$ given by the following equation:

and

$$
\eta_{t}=K-b_{\mathrm{d}} \log \left(t+t^{\prime}\right)
$$

$$
t^{\prime}=\frac{b_{\mathrm{d}^{\prime} C}}{i}
$$

$\eta_{t}$ is the overvoltage at time $t, K$ and $b_{\mathrm{d}}$ are constants; the latter is under certain circumstances equivalent to the Tafel slope, $i$ is the current density at the interruption of the electrolysis and $C$ the apparent electrode capacitance per unit area. Values of $t^{\prime}$ and $b_{\mathrm{d}}$ are indicated in the figures. $\left(b_{\mathrm{d}}=2.303 b_{\mathrm{d}}^{\prime}\right.$.)

The apparant electrode capacitance (pseudo-capacitance), calculated from $t^{\prime}$, depends strongly on the electrode potential as shown in Fig. 6. It decreases when the electrode potential increases, approaching a limiting value of $c a 3 \times 10^{3} \mu \mathrm{F} / \mathrm{cm}^{2}$ at high electrode potentials.

\section{Build-up of overvoltage}

Build-up curves were obtained with a galvanostatic technique. The capacitance of the double layer at the equilibrium potential was calculated from these curves, as usual; they lie between 10 and $30 \mu \mathrm{F} / \mathrm{cm}^{2}$.

Build-up and decay curves were also recorded successively by means of the electronic device mentioned in another paper. ${ }^{3}$ In these experiments the apparent capacitance was calculated from the initial slope of build-up curves obtained at different potential of the working electrodes. High values of the apparent capacitance were obtained in the region of $400-500 \mathrm{mV}$, in good agreement with previous results from decay curves. Typical results are shown in Fig. 7.

Unfortunately lack of sensitivity of the experimental arrangement hampered the investigation of the dependence of the apparent capacitance on electrode potential in the region of the lower overvoltage. 


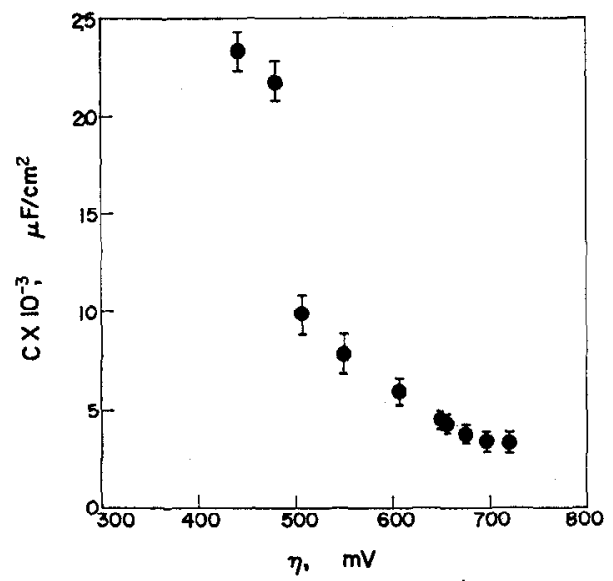

Fig. 6. Pseudo-capacitance obtained from decay curves $v s$ anode overpotential at current interruption, corrected for the pseudo-ohmic overpotential.

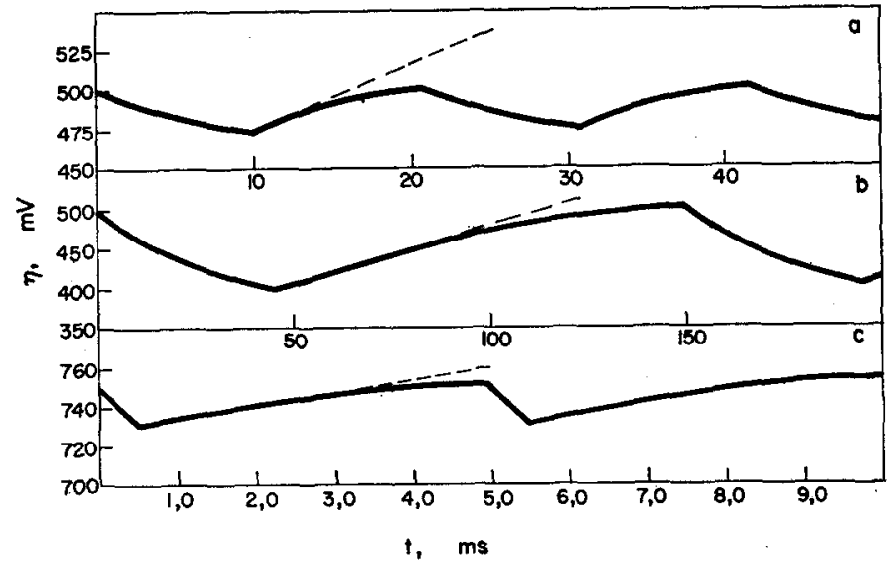

FrG. 7. Decay and build-up curves of anodic overvoltage taken at different frequencies of interruption.

a, $i=37 \times 10^{-3} \mathrm{~A} / \mathrm{cm}^{2} ; \mathrm{b}, i=37 \times 10^{-3} \mathrm{~A} / \mathrm{cm}^{2} ; \mathrm{c}, i=98 \times 10^{-3} \mathrm{~A} / \mathrm{cm}^{2} . \mathrm{a}, C=$ $18.5 \times 10^{3} \mu \mathrm{F} / \mathrm{cm}^{2} ; \mathrm{b}, C=25 \times 10^{3} \mu \mathrm{F} / \mathrm{cm}^{2} ; \mathrm{c}, C=3 \times 10^{3} \mu \mathrm{F} / \mathrm{cm}^{2}$.

Electrochemical system as indicated in Fig. 3.

\section{Formation of a residual cell}

More than $100 \mathrm{~s}$ after the interruption of the electrolysis current, the anode reaches a constant potential, measured against any of the reference electrodes employed. This residual potential is independent of the current density of the previous electrolysis and presents the characteristics of an apparent reversible potential. The graphite electrode is positive against the nitrate electrode in the residual cell; emf values are assembled in Table 2. The temperature coefficients of the residual cell is $-2.3 \times$ $10^{-3} \mathrm{~V} /{ }^{\circ} \mathrm{C}$, in the range investigated. The average enthalpy change of the cell reaction at $275^{\circ} \mathrm{C}$, for a one-electron process, is $-30.0 \mathrm{Kcal} / \mathrm{mol}$.

\section{Reaction products}

The gaseous products formed in the anodic reaction were analysed. Nitrogen dioxide and carbon dioxide were identified as the gaseous products yielded by the 
TABLE 2

\begin{tabular}{ccc}
\hline $\mathrm{T}$ & $\mathrm{Emf}$ & \\
${ }^{\circ} \mathrm{C}$ & $\mathrm{V}$ & Reference electrode \\
\hline 238 & $\mathbf{0 . 3 0 0} \pm 0.010$ & $\mathrm{Pt}, \mathrm{O}_{2}(\mathrm{~g}), \mathrm{NO}_{2}(\mathrm{~g}) / \mathrm{NO}_{3}-(\mathrm{l})$ \\
269 & $0.200 \pm 0.020$ & $\mathrm{Pt}, \mathrm{O}_{2}(\mathrm{~g}), \mathrm{NO}_{2}(\mathrm{~g}) / \mathrm{NO}_{3}-(\mathrm{l})$ \\
289 & $0 \cdot 196 \pm 0.010$ & $\mathrm{Pt}, \mathrm{O}_{2}(\mathrm{~g}), \mathrm{NO}_{2}(\mathrm{~g}) / \mathrm{NO}_{2}-(\mathrm{l})$ \\
317 & $0.146 \pm 0.010$ & $\mathrm{Pt}, \mathrm{O}_{2}(\mathrm{~g}), \mathrm{NO}_{2}(\mathrm{~g}) / \mathrm{NO}_{3}-(\mathrm{l})$ \\
\hline
\end{tabular}

electrochemical reaction at low temperatures. The ratio of these gases, evaluated by ir analysis, taking into account the absorption bands at $1618 \mathrm{~cm}^{-1}$ for nitrogen dioxide and $2349 \mathrm{~cm}^{-1}$ for carbon dioxide, was $2: 1$.

The formation of carbon dioxide involves consumption of the carbon electrode causing a continuous change of the electrode area. However the precaution was taken to pass only the minimum charge compatible with the experiments so that no macroscopic change of the electrode size could be detected. Current densities are therefore referred to the apparent electrode area as usual.

\section{DISCUSSION}

\section{The probable reaction path for the anodic reaction}

The anodic reaction occurring during the electrolysis of molten nitrates on graphite electrodes is evidently the stoichiometric reaction

$$
\mathrm{C}+2 \mathrm{NO}_{3}^{-}=2 \mathrm{NO}_{2}+\mathrm{CO}_{2}+2 \mathrm{e} \text {, }
$$

which can be described as the electrochemical combustion of the graphite electrode. It shows an appreciable polarization which clearly appears in the decay of the anodic overvoltage after current interruption. Polarization due to a concentration gradient of the ionic species should have a minor influence on the total effect, which is probably mainly activation polarization. It seems very unlikely that any ion other than nitrate participates in the electrochemical reaction as the initial reacting species at lower temperature.

The electrochemical oxidations of molten nitrate on platinum and graphite differ in (a) the magnitude of the overvoltage and (b) its dependence on time at initiation and interruption of electrolysis. On graphite the reaction is complex, shown by the magnitudes of the pseudo-capacitances obtained from decay curves and from their dependence on potential, indicating the participation of intermediates affecting the structure of the electrode/molten-salt interface. A decrease of pseudo-capacitance as the electrode potential increases could occur if the surface concentration of absorbed entities is high, when the pseudo-capacitance approaches the value of a Helmholtz double layer capacitance., ${ }^{5,6}$ The limiting value of the experimental pseudo-capacitance is larger than the value expected for a simple double layer structure by a factor of the order of $10^{2}$, but this difference will be considered later.

The reaction involves the oxidation of the graphite electrode and consequently attention must be paid to the thermal oxidation of graphite. The first step in this up to about $600^{\circ} \mathrm{C}$ is the attachment of molecular oxygen to the carbon network yielding a surface oxide. ${ }^{7,8}$ The reaction may also include steps representing the formation of more complex oxides and various equilibria with gaseous products. Published results ${ }^{9}$ on structural changes which occur during oxidation of graphiteshow the comparatively much higher oxidizing power of ozone at room temperature than 
that of oxygen at $300-400^{\circ} \mathrm{C}$; the time required for a certain degree of oxidation is greater for the latter. Furthermore, the heat of adsorption of oxygen on graphite is $97 \mathrm{Kcal} / \mathrm{mol}^{7}$ and the activation energy for desorption of $\mathrm{CO}_{2}$ is $80 \mathrm{Kcal} / \mathrm{mol}$.

The above facts suggest that discussion of electrochemical reactions on graphite must keep in mind the processes involved in the chemical transformation of graphite into volatile compounds. Transformation of graphite to carbon dioxide, the only product containing carbon at the temperature used, would involve the formation of surface oxide, after the initial discharge of nitrate ions on the electrode surface.

In the lower temperature region, the reaction path can be discussed on the basis of the detailed description already given for the probable mechanism on platinum. ${ }^{3}$

Tafel slopes obtained from current/voltage curves are the same as the slopes calculated from the straight line portion of the decay curves in the potential range from $400 \mathrm{mV}$ downwards. The kinetics of the electrochemical reaction, therefore, can be explained with the following set of consecutive reactions:

$$
\begin{aligned}
\mathrm{NO}_{3}^{-}+\mathrm{C} & \rightarrow\left(\mathrm{NO}_{3}\right) \mathrm{C}+\mathrm{e} \\
\left(\mathrm{NO}_{3}\right) \mathrm{C} & \rightarrow(\mathrm{O}) \mathrm{C}+\mathrm{NO}_{2} \\
\mathrm{NO}_{3}{ }^{-}+(\mathrm{O}) \mathrm{C} & \rightarrow \mathrm{NO}_{2}+\mathrm{CO}_{2}+\mathrm{e} .
\end{aligned}
$$

Reaction (1a) is the discharge of nitrate ion yielding a $\mathrm{NO}_{3}$ intermediate on the graphite surface. (1b) is the formation of a superficial oxide on graphite due to thermal decomposition of the intermediate. (1c) is the discharge of a nitrate ion on an oxidized surface of the electrode with the simultaneous formation of carbon dioxide.

Theoretical Tafel slopes when (1a), (1b) and (1c) are respectively rate-determining have been obtained as usual, assuming Langmuir adsorption. The results are summarized in Table 3. Evidently, the experimental Tafel slopes show that (1a) or (1c) can be rate-determining only within a certain potential range. To decide between these possibilities, we note the pseudo-capacitance. If step (1a) is exclusively rate-determining it is difficult to explain the high pseudo-capacitance, its dependence on potential and the existence of a reproducible residual cell.

TABle 3. Theoretical LIMiting tafel slopes for REACTION SCHEME 1 (Langmuir conditions)

\begin{tabular}{ccc}
\hline Slow step & Partial coverage & \multicolumn{1}{c}{ Tafel slope } \\
\hline (1a) & $\mathrm{X}_{\mathrm{NO}_{3}} \approx 0$ & $2 R T / F$ \\
(1b) & $\mathrm{X}_{\mathrm{NO}_{3}} \gg \mathrm{X}_{0}$ & $(\eta \rightarrow 0): R T / F$ \\
(1c) & $\mathrm{X}_{\mathrm{NO}_{3}} \ll \mathrm{X}_{0}$ & $(\eta \rightarrow \infty): \infty$ \\
& $\mathrm{X}_{\mathrm{NO}_{3}} \ll \mathrm{X}_{0}$ & $(\eta \rightarrow 0): 2 R T / 3 F$ \\
\hline
\end{tabular}

It is quite probable that (1c) becomes rate-determining if the degree of coverage of the electrode is large. The kinetic analysis shows that the Tafel slope at a low degree of coverage approaches the value $2 R T / 3 F$ and this slope was not observed.

It has been demonstrated recently in the electrolysis of molten nitrites on graphite, ${ }^{11}$ nitrogen dioxide oxidizes graphite only negligibly, and it should be discarded as a possible intermediate in the present case.

Additional information about the kinetics of the reaction may be obtained from the recent theory of electrode pseudo-capacitance, ${ }^{5,6}$ which shows the type of dependence of pseudo-capacitance on potential according to the degree of coverage by 
intermediates in the rate-determining step, and to the type of adsorption isotherm obeyed. Slopes for the overvoltage decay should approach those obtained from the Tafel plots if the degree of coverage approaches unity. When the degree of coverage is 0.5 or thereabouts the pseudo-capacitance is maximal and a region could exist where it becomes independent of the potential. The extent of the potential region where this coincidence is observed depends on the type of adsorption isotherm. Generally, the present values of $\mathrm{d} \eta / \mathrm{d} \log t$ fit, at least qualitatively, the above reaction scheme with (1c) as the rate-determining step.

The low value of the electrode capacitance at zero overvoltage will be further considered.

Molecular oxygen should have a minor effect on the overall process, since at the temperatures studied it oxidizes graphite at a low rate. The relative surface oxidation of graphite by oxygen or $\mathrm{NO}_{3}$ is comparable to the relative action of oxygen or ozone already mentioned. The effect of oxygen observed in the decay curves is probably due to a decrease in the rate of disappearance of the surface oxide at current interruptions, because of its participitation in various equilibrium reactions, such as those known in the oxidation of graphite.?

\section{The residual cell}

The residual cell observed after current interruption behaves apparently as a reversible system, which may be explained in terms of the reactions already discussed. The cell may be represented as

$$
\mathrm{Pt}, \mathrm{O}_{2}\left(\mathrm{p}=\frac{1}{3}\right), \mathrm{NO}_{2}\left(\mathrm{p}=\frac{2}{3}\right) / \mathrm{KNO}_{3}, \mathrm{NaNO}_{3}(1)(1: 1) / \mathrm{NO}_{2}\left(\mathrm{p}=\frac{2}{3}\right), \mathrm{C}(\mathrm{O}), \mathrm{C},
$$

(graphite positive) with half-reactions

$$
\mathrm{C}(\mathrm{O})+\mathrm{NO}_{2}+\mathrm{e} \rightleftharpoons \mathrm{NO}_{3}{ }^{-}+\mathrm{C},
$$

and

$$
\mathrm{NO}_{2}+\frac{1}{2} \mathrm{O}_{2}+\mathrm{e} \rightleftharpoons \mathrm{NO}_{3}-\text {. }
$$

Its emf in terms of the activities of the species involved in both reactions is:

$$
E=E^{\circ}-\frac{R T}{F} \ln \frac{a_{\mathrm{C}} \times a_{\mathrm{O}_{2}}^{1 / 2} \times a_{\mathrm{NO}_{2}}}{a_{\mathrm{C}(0)} \times a_{\mathrm{NO}_{2}}} .
$$

If the pressure of gases is nearly constant, and the surface activity of $\mathrm{C}(\mathrm{O})$ is proportional to the partial surface coverage $X$, (4) can be written

$$
E=E_{0}^{\prime}-\frac{R T}{F} \ln \frac{1-X}{X} .
$$

The constant $E_{0}{ }^{\prime}$ is, according to (5), the emf of the cell when the surface coverage of the electrode is 0.5 and its value is taken from the pseudo-capacitance/overvoltage curve. The overvoltage when the pseudo-capacitance is maximal is of the order of $400 \pm 100 \mathrm{mV}$, which means that $E_{0}^{\prime}$, at $500^{\circ} \mathrm{K}$, should be about $700 \mathrm{mV}$. Consequently, we can estimate the partial coverage at this temperature, since

$$
\frac{X}{1-X} \approx 10^{-4} ; \quad X \ll 1
$$


At zero overvoltage a very low surface coverage' by the intermediate oxide is thus obtained. This result explains the low capacitance systematically observed at the residual potential and suggests that the high pseudo-capacitance should be related to the formation of the intermediate on the surface. It is now understandable that the limiting pseudo-capacitance observed at large overpotentials is of the order of $10^{2}$ times the value found at zero overpotential. This figure, however, can be ascribed to an increase of the active area of the electrode occurring as the degree of surface oxidation becomes larger. The mechanism postulated for the oxidation of graphite helps also to explain this fact. In ideal graphite the first step in that process of oxidation is an edge attack, where there are free valencies; in less ideal graphite, defects at the boundaries between well graphitized carbon networks and more disordered arrangements may present points of attack, analogous to edges. ${ }^{7}$ Hence the degree of surface oxidation may be related to a change of active electrode area. Naturally, the active area decreases to its initial value once the amount of intermediate has appreciably diminished, as is the case when the potential of the residual cell is reached.

It should be pointed out that graphite electrodes ${ }^{12,13}$ may have a roughness factor of the order of 300 or 400 .

The residual cell just discussed is not observed at temperatures above $330-350^{\circ} \mathrm{C}$; here a different system is formed involving the spontaneous oxidation of the graphite electrode. ${ }^{14}$

\section{Activation energy}

As for platinum electrodes, in the present case the partial surface coverage by $\mathrm{NO}_{3}$ should be negligible compared to the partial surface coverage by oxygen atoms. Hence, from the suggested mechanism of the reaction, the theoretical limiting values of the rate equation, involving Langmuir adsorption for the intermediates, are respectively for $\Delta \varphi \rightarrow 0$ and $\Delta \varphi \rightarrow \infty$, the following

$$
V_{(\Delta \varphi \rightarrow 0)}=K_{\mathrm{a}} K_{\mathrm{b}} k_{\mathrm{c}} \exp (3 \Delta \varphi F / 2 R T)
$$

and

$$
V_{(\Delta \varphi \rightarrow \infty)}=k_{\mathrm{c}} \exp (\Delta \varphi F / 2 R T) .
$$

where $K_{\mathrm{a}}$ and $K_{\mathrm{b}}$ are the corresponding equilibrium constants of reactions (1a) and (1b), $k_{\mathrm{c}}$, the formal specific kinetic constant of the rate-determining step and $\Delta \varphi$, the potential difference across the electrical double layer. (6) and (7) take unit activity for nitrate ion and a symmetry factor of $0 \cdot 5$. At high positive overvoltage $(X \rightarrow 1)$ the rate of the electrochemical reaction is expressed by (7), and the temperature dependence of the extrapolated current density at zero overvoltage yields an activation energy, which may be related to the activation energy of the rate-determining step, $E_{(\mathrm{I}-\mathrm{c})} \approx E_{\mathrm{a}}=6.5 \pm 1.0 \mathrm{Kcal} / \mathrm{mol}$.

\section{Comparison with results on platinum}

It would appear at first sight permissible to neglect the participation of the intermediate $\mathrm{NO}_{3}$ in the reaction on graphite, assuming a direct formation of $\mathrm{NO}_{2}$ and $\mathrm{C}(\mathrm{O})$ in a single discharge reaction of a nitrate ion on the graphite surface. But the present discussion is principally based on results obtained for the anodic behaviour of molten nitrates on platinum electrodes and on the thermal oxidation of graphite; 
and the high degree of oxidation of the graphite surface reached at high overvoltages points to the intervention of the intermediate $\mathrm{NO}_{3}$ having a high oxidizing power.

Some details about its attachment to the electrode surface may be envisaged on the basis of the structural studies on molten nitrates ${ }^{15}$ and on covalent nitrates. ${ }^{16,17}$ It would be expected that the $\mathrm{NO}_{3}$ intermediate has a planar configuration. It is therefore very likely that the intermediate is initially bound to graphite through one oxygen atom and later decomposes to nitrogen dioxide with an oxygen atom left bound to the graphite surface. The formation of the surface oxide may be due to the larger number of unpaired electrons which are trapped in carbon. ${ }^{18}$ The tendency to oxide formation on graphite indicates that the latter favours the decomposition of the intermediate as compared to platinum, and this is decisive in changing the course of the reaction.

Acknowledgement-This work was in part financially supported by the Consejo Nacional de Investigaciones Cientificas y Técnicas of Argentina. W. E. T. thanks the Consejo for the fellowship granted.

\section{REFERENCES}

1. W. E. Triaca and A. J. Arvía, Electrochim. Acta 9, 1055 (1964).

2. A. J. Arvía, A. J. Calandra and W. E. TriaCA, Electrochim. Acta 9, 1417 (1964).

3. W. E. TriacA and A. J. ARviA, Electrochim. Acta 10, 409 (1965).

4. A. J. Arvía and W. E. Triaca, Electrochim. Acta 10, 1188 (1965).

5. B. E. Conway and P. L. Bourgault, Trans. Faraday Soc. 58, 593 (1962).

6. J. O. M. BockRIS and B. E. CoNWAY, Modern Aspects of Electrochemistry, No. 3. Butterworths, London (1964).

7. A. R. UbbeloHde and F. A. LewIs, Graphite and its Crystal Compounds, Oxford University Press, London (1960).

8. H. HaRker, H. Marsh and W. F. K. WYNne-Jones, in Industrial Carbon and Graphite, p. 291. Society of Chemical Industry, London (1958).

9. J. D. WATT and R. E. FrankLIN, Nature, Lond. 180, 1190 (1957).

10. G. BlyHOLDER and H. EYRING, J. phys. Chem. 61, 682 (1957).

11. A. J. Calandra and A. J. Arvia, Electrochim. Acta (in press).

12. F. P. Bowden and E. K. RIDEAL, Proc. R. Soc. A 120, 80 (1928).

13. B. M. BulYGIN, J. appl. Chem. U.S.S.R. (English translation) 32, 121 (1959).

14. A. J. Arvia and W. E. Triaca, unpublished results.

15. G. J. JANZ and D. W. JAMES, Electrochim. Acta 7, 427 (1962).

16. K. Brändle, M. Schmeisser and W. LütTKe, Chem. Ber. 93, 2300 (1960).

17. A. J. Arvia, L. R. Cafferatta and H. J. Schumacher, Chem. Ber. 96, 76 (1963).

18. D. J. E. Ingram and D. E. G. Austen, in Industrial Carbon and Graphite, p. 19. Society of Chemical Industry, London (1958). 